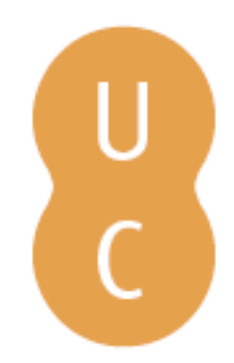

\title{
pommalina
}

\section{Redol e a literatura em devir}

Autor(es): Seixo, Maria Alzira

Publicado por: Imprensa da Universidade de Coimbra

URL

persistente: URI:http://hdl.handle.net/10316.2/38693

DOI: $\quad$ DOI:http://dx.doi.org/10.14195/978-989-26-1164-8_16

Accessed : $\quad$ 26-Apr-2023 12:03:42

A navegação consulta e descarregamento dos títulos inseridos nas Bibliotecas Digitais UC Digitalis, UC Pombalina e UC Impactum, pressupõem a aceitação plena e sem reservas dos Termos e Condições de Uso destas Bibliotecas Digitais, disponíveis em https://digitalis.uc.pt/pt-pt/termos.

Conforme exposto nos referidos Termos e Condições de Uso, o descarregamento de títulos de acesso restrito requer uma licença válida de autorização devendo o utilizador aceder ao(s) documento(s) a partir de um endereço de IP da instituição detentora da supramencionada licença.

Ao utilizador é apenas permitido o descarregamento para uso pessoal, pelo que o emprego do(s) título(s) descarregado(s) para outro fim, designadamente comercial, carece de autorização do respetivo autor ou editor da obra.

Na medida em que todas as obras da UC Digitalis se encontram protegidas pelo Código do Direito de Autor e Direitos Conexos e demais legislação aplicável, toda a cópia, parcial ou total, deste documento, nos casos em que é legalmente admitida, deverá conter ou fazer-se acompanhar por este aviso.

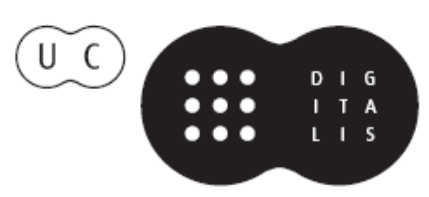




\author{
Maria Alzira Seixo \\ Universidade de Lisboa / Centro de Estudos Comparatistas
}

\title{
REDOL E A LITERATURA EM DEVIR
}

\author{
A Maria Graciete Besse, Ana Paula Ferreira e Vitor Viçoso, \\ especialistas da literatura de Redol
}

\section{Intenções}

A obra de Alves Redol tem sido objecto, neste ano da comemoração do seu centenário, de reflexões sobre a sua teoria e estética que tentam determinar, com mais justeza, a posição que o escritor ocupa na história da nossa literatura ${ }^{1}$. Para esse efeito é agora apoio basilar a obra Horizonte Revelado ${ }^{2}$, coordenada por David Santos, nomeadamente por incluir a biografia do autor tratado, intitulada "A História do Ceifeiro Rebelde», do punho e informação de seu filho António Mota Redol, num elenco de dados que transcende o escopo biográfico por fornecer

1 Este escrito constitui uma introdução teórica-crítica ao trabalho que tenho vindo a realizar a partir do confronto da $1^{\text {a }}$ ed. de Avieiros, de 1942, com a $5^{\text {a }}$, de 1968 , em que o texto deste romance se apresenta parcial, mas significativamente, refundido pelo seu autor. Enfrentando problemas que interessam a vários domínios da crítica, história e ensaística literárias, entendi ser esta reflexão passível de publicação em separado, até para evitar a extensão que o cotejo das duas versões exige. Por outro lado, escrevo aqui a pensar na figura académica de Ofélia Paiva Monteiro, que aliou à sua valiosa obra sobre Literatura Portuguesa uma significativa extensão em Estudos Franceses, labor pelo qual a comunidade científica muito lhe deve e, em particular, o Grupo Universitário de Estudos de Literatura Francesa da Faculdade de Letras de Lisboa, GUELF, e a revista Ariane, de minha responsabilidade até à aposentação. Pretendo, pois, com esta interversão de áreas universitárias "oficiais», ou "prioritárias", homenagear as suas capacidades no entendimento das exigências do Ensino Superior, e, muito em especial, a actuação científica exemplar que sempre, em face delas, demonstrou.

2 Volume de 314 pp, da autoria de David Santos e da equipa do Museu do Neo-Realismo por ele coordenada, primorosamente elaborado, não apenas pela rica e abundante documentação que exibe, como pelos estudos que nele se inserem. 
dados preciosos para a história das mentalidades, e para o historial de vultos e instituições do tempo.

Ao considerar o texto redoliano na perspectiva do que designo como a literatura em devir, pretendo significar fundamentalmente duas ordens de preocupações que esse texto me coloca: 1. relações entre Literatura e Tempo; e 2. importância da Leitura, enquanto noção tendencialmente conceptualizável ${ }^{3}$, na feitura da obra literária ${ }^{4}$.

No que respeita à relação da literatura com o tempo, importa ter em conta a dimensão epocal dos textos (sobretudo na sua vertente sócio-ideológica) tanto quanto a própria temporalidade literária, susceptível esta de apreensão nas modalidades adoptadas (ou criadas) da textualização, as quais é possível percepcionar em análises discursivas da temporalidade da escrita. História, orgânica social e respectiva ideologia condicionante, bem como textualidade, são factores decisivos num pensamento das suas mútuas relações que encontra a sua melhor determinação, mesmo se em aberto (e talvez por isso mesmo) na obra de Roland Barthes $^{5}$. No plano das particularidades da escrita que constituem fundamento do literário se concentra a oscilação, por certo variável, entre uma perspectiva de análise poética objectiva e regrada, e uma observação das significações discursivas susceptível de acesso mais lato (o do leitor comum), que é mister aliar à do leitor especialista, que as considera em função dos efeitos de multiplicidade desenvolvidos pela manifestação do acto criativo.

Literatura em devir é, pois, o modo como aqui se designa a rede das relações temporais de vária ordem que, implicando a Leitura no próprio modo de existência do Literário, pressupõem o cometimento do sujeito (da leitura e da escrita) no texto $^{6}$. Esse(s) sujeito(s) cria(m), do autor ao crítico, do leitor comum ao estudante de Literatura, etc., movimentos de espiral na recepção do objecto estético de

3 Tenho em mente, entre outros, os trabalhos de Michel Charles, Rhétorique de la lecture, Seuil, Paris, 1977, de Umberto Eco, Lector in Fabula, Seuil, Paris, 1979, de Roland Barthes, Essais critiques IV, Le bruissement de la langue, Seuil, Paris, 1982 e 1984.

4 Como ficou dito na nota 1., o que se segue decorre primacialmente do confronto das duas versões de Avieiros, mas acontece com alterações significativas que se verificam noutras obras suas, por ex. Fanga.

5 Evoco em particular os Essais Critiques, III e IV, publicados por François Wahl, respectivamente, L'obvie et l'obtus e Le bruissement de la langue, Seuil, Paris, 1982 e 1984.

6 Percebe-se que me fundo aqui no pensamento aberto pelo texto de Barthes «La mort de l'Auteur", de 1968 (revista Manteia). Republicado em Le Bruissement de la langue, ver Nota 3. 
escrita que, postulamos, desenvolvem formas várias da respectiva ressonância: seja na leitura crítica de notícia, seja na de comentário, na do ensaio aprofundado, no trabalho académico ou de outra ordem, que completam, e prolongam, o tempo da concepção do literário, que assim se entrança no dizer sobre ele, ou a partir dele, criando arredores localizados.

Ora a leitura a eito da obra de Alves Redol a que recentemente procedi, e aliás me permitiu entender melhor a sua estética e o desenvolvimento de concepções estilísticas e efabulativas que vai assumindo, iluminou-me quanto a um aspecto que se me antolha decisivo na sua composição da ficção: o do modo como reescreve os seus textos, em certas reedições. Isso é particularmente evidente, e muito elucidativo, na refundição do seu terceiro romance, Avieiros (Portugália, 1942), para a $5^{a}$ edição (Europa-América, 1968), sobretudo se se considerar que tal refundição constitui o seu último trabalho literário ${ }^{7}$, contemporâneo da série infantil da Flor.

António Mota Redol considera ${ }^{8}$ que essa refundição dá praticamente origem a um novo romance, intuindo razões como as de "Redol, nos anos 50, [pensar] que o Neo-Realismo [tinha] de tomar outros rumos, mais conducentes com a nova realidade nacional e mundial, com maior atenção aos aspectos formais»". E sublinha também o facto de o autor de Barranco de Cegos ter sido muito sensível às críticas de seu amigo, o escritor e crítico Mário Dionísio, que por várias vezes lhe apontara insuficiências de construção e impropriedades estilísticas, sem obliterar o valor fundamental que na sua obra encontrava. Daí que o atento filho do Escritor, e seu exegeta atento, chame a atenção para o paratexto redoliano, muito rico e substancial, e importante, sublinho eu, não apenas para que se compreenda a motivação das refundições praticadas, mas por constituir uma escrita complementar dos textos, nessa mesma relação leitura-escrita em que se baseia o nosso pressuposto hermenêutico de uma literatura em devir.

\footnotetext{
7 António Mota Redol, em "A História do Ceifeiro Rebelde. Uma biografia de Alves Redol", Horizonte Revelado, pp. 308-309, põe em relevo o facto de, durante anos, Redol não publicar reedições de alguns dos seus livros. No caso de Avieiros, entre a $4^{\mathrm{a}}$ ed., de 1945, e a $5^{\mathrm{a}}$, de 1968, o livro não surge reeditado (algo de semelhante sucedendo com Gaibéus e Fanga), sendo lícito supor, já que essa $5^{a}$ edição apresenta uma refundição quase completa da obra, que Alves Redol projectara desde cedo essa remodelação.

8 Op. cit., p. 308: "5a edição de Avieiros, um novo romance», em que até se chama esta proposta de entendimento ao título da penúltima rubrica da extensa Biografia apresentada.

9 Ibidem, p. 309.
} 
Na verdade, o Portugal dos anos quarenta, com Salazar e os desastres europeus, não é o mesmo, em estética literária, que o Portugal dos anos cinquenta, e muito menos dos anos sessenta. Aquela primeira década, que viu florescer o Novo Cancioneiro, a ficção de Soeiro Pereira Gomes e de muitos outros escritores cuja obra, evoluindo ou não, se prolongou ao longo de Novecentos, era a época da maturidade de Aquilino, Almada, Teixeira-Gomes, Nemésio e Miguéis, mestres de saber oficinal que se não compadecia com os jovens intentos de quem queria mudar o mundo com a palavra. E a década de cinquenta apresentava já os primeiros jovens romancistas de concepções novas, que o eram inteiramente: Agustina, Vergílio Ferreira refundindo-se a si próprio, Ruben A. irrompendo na ficção, Augusto Abelaira. Quanto aos anos 60, não só eles são os da maturação e fulgor desses últimos, como em relação a eles aprofundam perspectivas e rompem modelos: Almeida Faria os encabeça, Nuno Bragança e Maria Velho da Costa se afirmam, e Maria Gabriela Llansol emerge, para regularmente se ir firmando, e avançando. De 1942 a 1968, pois, um quarto de século incessantemente inovador e pujante na qualidade dos textos, não deixa indiferente um escritor que medita o que escreve e o que sobre ele escrevem (Redol, incansável leitor!), escrevendo e lendo e ansiando reescrever, pregando as palavras no tempo e deste recebendo, e dos outros (com quem escreveu e para quem escreve também), estímulos mais para novas palavras empregar. Em novidade que como "palavra-pele»" lhe surge, "palavras frementes e insubmissas como poldros deslumbrados em plena liberdade de sol »11.

Tenho afirmado, em escritos periodísticos ${ }^{12}$, que o Neo-realismo, entre várias características que os seus analistas não se têm cansado de estudar, produz uma ficção que, no essencial, repousa numa aparente composição oitocentista do romance (a intriga de entrecho e desenlace organizados por personagens radicadas numa amosfera espaço-tempo), veiculada numa representação canónica da circunstância efectiva (o chamado «real») que é muitas vezes comunicada no timbre prosaico da «realidade tal qual acontece», ou no timbre lírico do «ai do lusíada, coitado!» a acompanhar sofrimentos e opressões sociais. E o Neo-realismo, insisto, apresenta uma característica de modernidade que não tem

\footnotetext{
10 Avieiros, $5^{\text {a }}$ ed., Europa-América, 1968, pp. 18 e 19.

11 Ibidem, p. 17.

12 Verbi gratia, "Cadências do Mundo", JL, Jornal de Letras, Artes e Ideias, Dezembro de 2011.
} 
sido valorizada (talvez porque, reduzido a emparelhar com os homólogos italianos, a filiar-se no romance nordestino brasileiro, e a reconhecer-se que bebeu na ficção soviética estalinista, tem escassos parceiros europeus - algum Aragon, certo Vailland, e pouco mais), e é a de que, antecedendo tibiamente as irrupções "hors-texte» da ficção de Almada Negreiros, ou, ao invés, as inclusões textuais do mundano perecível nas inscrições livrescas de Gabriela Llansol, vem usar a palavra como acção de protesto, como indiciação objectual do mal, como indicativo do coro de insubmissos ou do «solo» da revolta sacrificial. (E veja-se como a História Literária pode sancionar, em (in)certa perspectiva de leitura, um percurso que assente em sequências como a de J'accuse de Zola, Locus Solus de Raymond Roussel e, até, a obra de Artaud. Não é impensável, e será pensado noutro local). A palavra-acção, que o escritor neo-realista busca, é decerto diferente da palavra-acto que a modernidade de meados de Novecentos apoiou; mas, a mostrar que são parentes, e até decorrentes, está a obra de Carlos de Oliveira, neo-realista que se prezou, no trânsito (que, ensaisticamente, ainda não vi observado, sem peias!) que liga Casa na Duna, Uma Abelha na Chuva e Finisterra.

O excurso anterior pretende apenas sublinhar que 1. a estética da representação aparecia como instrumento indispensável à configuração ficcional da palavra literária de alcance pragmático, mesmo se postergada já por alguns escritores, como no caso-limite do Húmus de Raul Brandão; e que 2. a carga histórico-ideológica do romance neo-realista, forçada a admitir, pelos seus próprios pressupostos (que António Pedro Pita, Carlos Reis, Vítor Viçoso e outros têm aprofundadamente encarado ${ }^{13}$ ), os binarismos de expressão que o próprio desenvolvimento fabular, na narrativa literária de qualidade, se encarrega de matizar ou mesmo de extirpar - veja-se Barranco de Cegos, que em Redol não é disso exemplo único -, essa carga histórico-ideológica, insisto, exigia um trabalho da textualidade que poucos cultores do neo-realismo entenderam (e daí que as acusações de simplismo fossem justas em muitos casos), o qual Carlos de Oliveira praticou na sequência Casa na Duna, Uma Abelha na Chuva e Finisterra, e de que o melhor exemplo é provavelmente a obra

13 Ver a "Bibliografia” de Alves Redol na obra atrás citada, Horizonte Revelado, e bem assim inúmeros textos e documentação em Batalha pelo Conteúdo, com coordenação de David Santos, Câmara Municipal de Vila Franca de Xira e Museu do Neo-Realismo, Outubro de 2007. 
completa de Augusto Abelaira, se bem que iniciada já na fase que, no exemplo anterior, corresponde ao segundo romance citado, mas que, se se considerar a sequência $A$ Cidade das Flores, As Boas Intenções e Bolor, dará a tal excurso a devida razão.

Onde se situa então a obra de Redol, neste propósito de trabalho? Que sequência nela se pode isolar? Várias, se tivermos em conta que em Redol estão entrosadas vias de construção romanesca diferenciadas: a da denúncia que exige uma actuação (neo-realista no $1^{\circ}$ grau, diria, com os quatro primeiros romances, de Gaibéus a Fanga, de 1939 a 43), a da extensão do conhecimento a circunstâncias locais e temporais outras (com a passagem ao Douro e o rasgo compósito do "Ciclo de Port-Wine», encetando este o cultivo reflectido do romance histórico, de Anúncio a Vindima de Sangue, 1945 a 53) e, de Olhos de Água a O Muro Branco, 1954 a 66, a fase em que História, símbolo e trabalho de escrita se apuram e dão uma mundividência já algo diferenciada. Fases, digo bem - pois, se sequência posso isolar, neste estádio da investigação, será a de Fanga, Os Homens e as Sombras e Barranco de Cegos. Será..., uma vez que é aqui que se introduz a questão da reescrita, e, portanto, da categoria hermenêutica que designei por "literatura em devir", isto é, a que lida não apenas com os intentos da doutrina neo-realista que o escritor funda e persegue mas, sobretudo, com a sua preocupação com o que escreve, o que vai escrever e o que escreveu, o qual decide, em muitos casos, reescrever.

E assim entrevemos uma das tais espirais, assinaladas supra, que constituem esse movimento, diferenciado embora na sua 'agência' (como se dirá em Teoria Pós-colonial, e mencionar esta não é totalmente exorbitante), que enrola escrita e leitura, o qual nos aparece como uma das matrizes da obra de Redol, e de que as refundições dos primeiros romances dão conta. Procurando, então, uma transformação da realidade nos textos, e uma transformação dos textos que possa operar na própria realidade, a palavra mágica neo-realista heroiciza gente, leva a aniquilar gente, e torna a Literatura, entendida enquanto fala do homem, instrumento do perigo e da ameaça a abater. Foi este o impacto do Neo-Realismo literário nos anos quarenta e cinquenta, e não foi pequeno, pelos efeitos de censura que sofreu. A sua estética não bania a ética, o que, em estudos literários, causa problemas, mas irrecusavelmente entra no contexto. Por esta ordem de ideias, a modernidade novecentista (que rejeita a arte como símile e 
como reprodução) reforça-se com esta palavra de tipo pragmático ${ }^{14}$, que o Neo-Realismo pressupõe.

\section{Tenções e tensões}

Recordo um poema de Sebastião da Gama, dos anos sessenta, que em princípio não tem nada a ver com o Neo-realismo, e conheci na voz de David Mourão-Ferreira, numa aula de Teoria da Literatura, em 1958, quando eu era sua aluna:

A corda tensa que eu sou,

o Senhor Deus é quem

a faz vibrar...

Ai linda longa melodia imensa!...

- Por mim os dedos passa Deus e então

já sou apenas som e não

se sabe mais da corda tensa... ${ }^{15}$

Nele impressiona a relação entre intensão e intenção, na medida em que se postula a existência de um impulso exterior (superior) que, na criação poética, é estímulo decisivo, revelando-se ela na intensidade melódica que a tensão humana produz. O poder (potencialidade) reside na própria existência do indivíduo, que a entidade superior (que o é por a reconhecermos como tal) atinge, permitindo à vibração acontecer. A metonímia do "Som» alude à criação literária, e a intencionalidade individual dela parece esbater-se ante a acção que no poema se pressupõe como divina. (Há pouco, falei em palavra "mágica», o que lhe é

14 A teoria pragmática, no plano linguístico-textual, tem como obras fundamentais, as de Austin, How to do things with words (trad. fr. Quand dire c'est faire), Oxford University Press, 1962, e de Searle, Speach Acts, Cambridge University Press, Londres, 1969, tendo sido desenvolvida por Teun A. Van Dijk (vd. Texto y Contexto, trad. García Berrio, $3^{\mathrm{a}}$ ed., Catedra, Madrid, 1988) e, na esfera do literário, por Mary Louise Pratt, vd. "Conventions of Representation. Where discourse and Ideology meet, in Willie Van Peer, The Taming of the Text, Routledge, London, 1989; "paperback", 1991.

15 Poema introdutório de Serra Mãe, Ática, Lisboa, 1963, livro de estreia do autor. 
coextensivo, por aliar o trabalho poético a uma esfera estranha, que não domina o «trabalho" mas centra a "poiesis».) Curioso, porém, é que, atribuindo a Deus o feito de percussão, e dando o sujeito do texto como instrumento, se elude o trabalho melódico-poético para o confinar ao efeito (em onomatopeia litaníaca: "Ai linda longa melodia imensa!"), vincando em contrapartida, nesse feito, o que ele tem de artesanal: pela interferência da exclamação, reactiva ou popular ("ai»), pela lengalenga melódica, pela concentração nesta de aliterações e assonâncias, e pelo trabalho dos espaços e transposições (enjambements) no interior do verso, como unidades de significação, que já não é acto de Deus mas obliteração de si, na inflação poética produzida. A corda esvaíu-se, ficou o som do texto a ressoar. A expressividade.

As formas de uma tenção do texto (intenção ou contenda, luta pela expressão ou intento poético) perdem-se, pois. E a tensão que o provoca (a corda tensa, a intensidade do que há a dizer) também se secundariza, ficando, em importância central, a intensidade da linguagem obtida, isto é, o trabalho poético.

Ora o Neo-realismo liga-se às intenções sócio-políticas, que a sua estética pressupõe. Mas o culto da frase limpa e linear, em registo de descrição-constatação, que caracteriza o autor de Esteiros; a impressividade lírico-épica que a obra de Redol em geral produz; o classicismo simbólico de Carlos de Oliveira, fissurado em múltiplas significações; a própria oscilação subjectiva que, em afixação da má-consciência de pactuar com situações vigentes, ou lúdico registo dela, a escrita de Abelaira pressupõe - nenhuma destas formas poéticas tenciona dizer, por ex., que é preciso lutar contra o poder opressivo, ou que vamos todos libertar a classe operária. (Quem pode tencionar dizê-lo é o seu autor, mas não as suas formas de expressão que, se forem directas - reproduções de significado sem elaboração estética - serão risíveis, e falham na sua função sócio-cultural). Mas a tensão poética que essas formas apontadas criam no texto, e o movimento estabelecido entre texto e leitor, e entre este e outros textos que lê, ou que vai escrever, isso, sim, diz tal! Um pouco (noutra esfera de sentido) como no poema de Sebastião.

E esse é o movimento em espiral que salientei de início, e convoca as ressonâncias resultantes da relação entre as figuras do escritor e do leitor. 


\section{A tenção de Avieiros}

Há uma intenção social evidente, reconhecida e indesmentível, na obra de Redol: a da «aguerrida batalha pelo conteúdo em literatura», que "parecia urgente» aos «jovens que ansiavam plantar os alicerces para um novo tipo de cultura extensiva às grandes massas ausentes da actual, preparando pelo alargamento à quantidade a síntese posterior da qualidade» (afirmação do famoso passo no prefácio à $6^{a}$ ed. de Gaibéus, 1965). Mas é também notória a tenção de ir promovendo a referida "síntese», quando, durante os anos sessenta, surge Fanga, com a $6^{a}$ ed. revista e largamente prefaciada, em 1963, iniciando a maré das correcções e dos prefácios reflexivos, que vai até Gaibéus, na 6ª ed. de 1965, e a Avieiros, na $5^{\mathrm{a}}$, de 1968 - ficando de fora Marés, mas sendo lícito supor que, se o Autor nos não tivesse deixado logo em 1969, esse singular romance da actividade comercial teria sido também sujeito a atenta ponderação. Aqui anoto que se trata de um romance que urge revisitar.

A intenção literária, de objectivos marcadamente textuais, vai, pois, crescendo na obra de Redol. E desses quatro primeiros romances, genericamente marcados pelo gosto documental enfatizado na epígrafe de Gaibéus, será em Avieiros, de 1942, marcada pelo prazeiroso desdobrar do paratexto (que é, em si, uma forma de ligar o livro ao seu arredor), indiciador do próprio texto, mas já também da reflexão sobre ele: primeiro, a "Dedicatória» a Jerónimo Tarrinca, em três linhas que descrevem a sua "Liberdade» por "caminhos" do "Tejo»; depois, a explicação, de teor invocativo, do que são esses «vagabundos do Tejo» que vivem nos barcos a vida inteira, ocupados em pesca, venda e transportes; e, enfim, uma breve epígrafe, em jeito de inscrição, que lhes traça a origem, a razão migrante, e o gosto do mar que projectam na Borda de Água. Na $5^{\text {a }}$ edição, de 1968, a Dedicatória alarga-se, e um longo Prefácio ("Breve história de um romance») fornece dados mais concretos sobre os Vagabundos do Tejo, com quem o escritor entretece lances autobiográficos: uma experiência de convívio e a lição de vida, com o avô Venâncio, o avô campino João Redol, casado com Ana da Guia, essa avó que descobre ser também avieira. Textualizando o prefácio também, interpela poeticamente a amiga Luísa Dacosta, colega de A-Ver-o-Mar, sobre o amor de ambos pelas águas. 
Ora o paratexto, enquanto conjunto de textos que preparam, na publicação, o texto em si, configura no escrito a sociedade em que se insere, e pode insinuar uma sua história, mesclando a tenção da escrita com a intensidade com que ela irá revelar-se. E esse prefácio centra de facto a intenção do romance: dar «um tema que me apaixonou», com uma "variação" (datada de 1968, vinte e seis anos depois!) "para que cheguei a admitir título diferente», e que "resultou de uma longa batalha, longa e exaltada e amorosa, entre um homem-escritor e o seu passado-futuro".

Duas ideias teórico-literárias nos prendem, neste movimento de leitura-escrita empreendido pelo escritor, enredado na temporalidade de ambas, e empenhadamente por ele descrito: a ideia de batalha e a ideia de tempo. A ideia de "batalha», que o leitor ligará à "batalha pelo conteúdo», do prefácio ensaístico de Gaibéus ("Breve memória» da 6a ed., 1965, que tem feito História), surge, em Avieiros ("Breve história» da $5^{\mathrm{a}}$ ed., 1968), algo secundarizada (pois se afirma: "mantenho o tom da $1^{\mathrm{a}}$ edição, mas sirvo-o com outra ferramenta", sendo que o «tom» parece aqui pertencer mais ao plano do conteúdo que ao plano da expressão ${ }^{16}$ ), já que é o estilo e a efabulação, a composição romanesca em si, que vem a primeiro plano. E a ideia de "tempo" impõe-se, nessa "longa batalha, longa e exaltada e amorosa, entre um homem-escritor e o seu passado-futuro", tomando o escritor consciência, na sua concretização em acto (lendo o que os

16 Esta discussão sobre "forma" e "conteúdo" apresenta sempre complicações, dado que os respectivos termos conceptuais são susceptíveis de significação diferente de acordo com as teorias literárias e/ou filosóficas que as determinam, nunca sendo unívocos. Há uma tradição ocidental da oposição forma/ conteúdo que atribui a este as significações e àquela os modos de as conformar. Porém, não é ocioso lembrar que, durante a $2^{\text {a }}$ metade do séc. xx, a Semiótica Literária, com a última plêiade de teóricos dos Estudos Humanísticos que a nossa actualidade conheceu (Foucault, Barthes, Lévi-Strauss, Lacan, Derrida, Todorov, Kristeva), instituíu, na senda do linguista dinamarquês Hjelmslev e com o semiólogo Greimas, o entendimento da Significação como sendo a relação entre dois planos, o da Expressão e o do Conteúdo (na senda de Einstein, $S=E R C$, isto é: a significação é a relação entre a expressão e o conteúdo), possuindo cada um destes planos dois sub-planos (forma e substância). Deixa de haver, assim, oposição entre forma e conteúdo, porque há uma forma da expressão e uma forma do conteúdo, e ambas fundamentam (e é o caso que nos interessa) a construção do objecto literário. Tudo o mais é substância (ideológica, num extremo; fonético-instrumental, no outro extremo, também participantes, em Literatura, mas com outro tipo de incidência), a qual, em rigor, não chega a fazer parte do texto, é-lhe exterior. A percepção da significação literária dentro destes parâmetros teóricos torna estas questões muito mais claras - mas a Desconstrução de Fim-de-Século entendeu banir essa possível clareza, resolveu pulverizá-la e desacreditá-la, e... pufff!, foi um ar que deu às tentativas de rigor nos Estudos Literários, que actualmente, sem essa base (mesmo que reconstruída), não se sabe bem o que são, para gáudio de tecnocratas e anti-humanistas. E, pelos vistos, nem está fazendo bom proveito às actuais gerações. 
outros escrevem sobre si, relendo-se e reescrevendo-se), do devir da literatura. Devir que se materializa na Literatura enquanto História (nos prefácios, Redol vai rejeitar a par e passo o Naturalismo, o que também é interessante, porque se refere - como a sua época - muito mais a concepções 'herdadas' da estética naturalista que a essa estética em si mesma, v.g. a sua relação amor/rejeição com Fialho de Almeida, por quem se sente estilisticamente influenciado), na Literatura enquanto Memória (se os seus prefácios têm componentes autobiográficas, tal dever-se-á menos ao seu pendor para as histórias de família, penso, que à temporalização das temáticas e assuntos que deseja tratar, e ao respectivo modo de o concretizar) e na Literatura enquanto relação Escrita-Leitura, cuja concepção tenho vindo aqui a propor.

A intenção literária, de algum (mas profundo!) modo, agita a intenção social do escrito de Redol, que é um escritor extraordinariamente sensível à textualização (um dos seus livros mais importantes, nesta perspectiva, é Olhos de Água, que mescla a lenda, a historieta, a descrição, o documento, a evocação e outros vários registos, para a construção textual de um lugar - local, localidade - que é uma espécie de «nenhures», e se agiganta afinal em todo um livro com a pulsação de uma vivência que, só quando já temos a leitura adiantada o descobrimos, é a própria vivência da escrita). E ele percebe, na "Breve história», que é afinal o modo de dizer que, verdadeiramente, diz aquilo que se pretende dizer! Isto é: há uma tensão textual que, uma vez conseguida (no equilíbrio entre a "corda tensa" de Sebastião e a vibração que ela produz, por mágica-divina-e-tão-humana percussão), exprime, por si só, a mensagem que reside fora do texto ("Vamos libertar as classes exploradas!») e, para nele entrar, é necessário que ele lhe conforme a entrada (explícita ou só insinuada, isso já se torna indiferente e é apenas característica de autor) na sua específica configuração; e Avieiros terá de ser: a história narrada de Maria do Rio e de Tóino do Vala, sua fainas, lutas e perdas, seu desconcerto na vida, sua busca do conchego que marinhas e terras permeiam, e só em miragem de horizontes distantes parece subsistir. Em narração de extremo e extremoso cuidado, da qual o escritor cuida ao longo de vinte e seis anos, em história também sua de aprendizagem e amor, amor-ódio talvez, e tanto dela cuidou que há um romance do romance a contar: 
Vivi um drama verdadeiro com este romance.

Não me compadecia em repisar histórias no almofariz da mediocridade, conhecia o perigo das vozes alheias que ainda me dominavam, estava longe de estabelecer o equilíbrio entre a paixão e a lucidez, entre o coração quente, em fogo, e o raciocínio quase matemático, empreendedor e terso. O domínio da efabulação, a chave da vida inteira de cada personagem, o tom justo, mesmo quando exaltado, a simplicidade, a palavra. A palavra-pele que cobre cada passo de um mundo emaranhado de sugestões inquietas e inquietantes, a palavra-pele que só ela pode viver ali, exactamente ali, como a das minhas mãos ou a das tuas, que enfeixa músculos e tecidos, sangue, vida.

A nova versão de Avieiros na $5^{\mathrm{a}}$ edição, de 1968, dá-nos um belíssimo romance feito dessa "palavra-pele que só ela pode viver ali, exactamente ali». O qual, a meu ver, não invalida o intento determinado, a frescura sentimental, o delineio um tanto impressionista (o espectro de Fialho espreitando, talvez... mas muito do que encontro em Olhos de Água, mais amadurecido, o vejo também ali) do texto da $1^{\text {a }}$ edição.

E o leitor académico, ou devotadamente estudioso, terá, no confronto de ambos, amplo ensejo para exercer seus dotes ou sabença em crítica genética, em crítica textual, e em qualquer tópico de estudo que requeira o pôr em prática de modos, e tenções (na maior parte das vezes polemistas ou dramatizantes), que encarem a maneira que tem a Literatura de encontrar o tempo, e o tempo (particularmente o tempo do escritor, ou os seus vários tempos) de encontrar (fascinadamente, ou conflituosamente) a Literatura.

\section{A tensão em Avieiros}

Falta-nos mencionar o participante fundamental desta justa que Alves Redol empreendeu com o seu terceiro romance, e converteu o filão básico da intenção social dos primeiros livros numa reflexão de poética que irá enriquecer e densificar a sua obra completa. Refiro-me a seu amigo Mário Dionísio, grande poeta e

crítico, que entrara entretanto, com os contos de O Dia Cinzento, 1944, também na ficção neo-realista, onde já os Poemas, de 1941, lhe haviam marcado o lugar. 
A refundição de Avieiros deve-se, em grande parte, à acção da sua leitura e da sua crítica $^{17}$. Com efeito, Mário Dionísio dedica, na Seara Nova, uma das célebres «Fichas» à crítica de Avieiros, após a saída deste romance, a «Ficha 5», começando por salientar que ele foi «a primeira pessoa a trazer para a nossa literatura de ficção personagens e problemas até então nela desconhecidos». Faz jus, pois, à "batalha pelo conteúdo» reivindicada pelo autor de Gaibéus. E não lhe poupa elogios: «um nome que nunca mais poderá desligar-se da nossa literatura actual», o «introdutor», nela, de matérias até então não afloradas, vincando que "Avieiros representa um franco progresso" sobre os livros anteriores, e que Redol, "se se autocriticar [...], poderá vir a ser com tempo, trabalho e cultura, um dos nossos mais fortes e mais humanos escritores do futuro" ${ }^{18}$.

Mas, sublinha o autor de $A$ Paleta e o Mundo, Redol «não quis ver a diferença entre um romance e uma reportagem "19, e enferma de vários defeitos de estilo e composição, que enumera com empenho: 1. a abundância do que com valor causal (ex. «A companheira fora acompanhá-lo à outra margem e ele abalara terra dentro, de sacola ao ombro, sem se voltar uma vez só - que $e^{20}$ o adeus não remedeia males e deixa penas); 2. a imagem que afasta a palavra da ideia comum, e cito M. Dionísio: "Porque não escrever como toda a gente fala? Por ex. Porque carpir em vez de chorar, ao raro em vez de raramente, beijar a terra em vez de cair, etc.?»; 3. o burilar da frase, ex. "As searas pediam foices e os gados reclamavam restevas». Mário Dionísio censura ainda a construção romanesca, que, a seu ver, «não apresenta mais que a ossatura dum romance» ou "O ponto de partida para um romance», sendo "os casos que o autor nos apresenta» meros "casos isolados, riquíssimos de observação, mas falhos de vida», apresentando «casos para a existência dos quais arranjou uns personagens, óptimos na sua linha geral mas que não chegam a verdadeiros personagens, que não chegam

17 É fascinante mergulharmos no acervo documental do percurso crítico de Mário Dionísio sobre a obra de Alves Redol, patente não apenas nos vários e importantes textos que sobre ele escreveu, mas ainda na correspondência trocada entre ambos, e nas dedicatórias escritas nos seus livros, de um para o outro (mais um nível do paratexto, este oficioso, a considerar...). E ainda, tarefa curiosíssima!, percorrer a obra de Redol existente na Biblioteca do autor de A Paleta e o Mundo, e ir verificando as observações à margem, os sublinhados, os traços de valor assertivo ou dubitativo, etc. Este manancial aguarda investigadores no Centro Mário Dionísio, na Casa da Achada, reunido em oferta que só exige o trabalho do pensamento, e é uma dádiva a quem queira trabalhar!

18 As citações de "Ficha 5" respeitam à Seara Nova de 11 de Abril de 1942.

19 Ibidem.

20 Sublinhados meus. 
propriamente a viver, a mexer-se, a ter aquela acção (no sentido exterior e principalmente interior) que é talvez a primeira característica dum romance» ${ }^{21}$. Direi que Dionísio é um tanto excessivo na sua crítica, mas os que lhe conheceram o rigor e a exigência (em relação a si próprio também!) ${ }^{22}$ compreendem o modo duro e impiedoso com que ele trata o amigo e colega. Porque há em Dionísio uma exigência humana de verdade, e criticar um colega é valer-lhe com a sinceridade da expressão amiga dos defeitos, para que ele os emende, em vez de os camuflar para o manter no erro. Há uma ética do trabalho e das relações humanas da qual estes dois homens são, neste caso, um exemplo a fixar e a seguir. Porque escrita, leitura e crítica não funcionam aqui como ficções do convívio, são aquilo que ambos queriam: a seriedade do labor artístico.

A verdade é que saem de Avieiros quatro edições nos três primeiros anos de existência deste livro, sinal de que o público o lê e o quer; mas, como salienta António Redol na Biografia, a partir de 1945 as reedições suspendem-se. Ora não é crível que o ritmo de vendas tivesse abrandado: o entusiasmo pelo Neo-Realismo intensificava-se, e Redol foi sempre um êxito junto do público. E, em 1968, um ano antes da sua morte, o escritor de Vila Franca de Xira reedita enfim este livro, substancialmente refundido.

E que livro vem a ser este agora? A $1^{\text {a }}$ edição revista, ou corrigida? Uma remodelação completa? Uma nova versão, como o autor lhe chama e, a certa altura do prefácio - dessa "Breve história de um romance» que considerámos na parte anterior - uma "variação», diz ele, como em partitura musical. Isto é, ficámos com dois livros com o mesmo título: a $1^{\mathrm{a}}$ edição, reeditada três vezes e nunca retirada, e, por conseguinte, no plano da Crítica Textual, continuando a ser um texto vivo e actuante. É certo também que essa crítica textual estipula que seja a última edição publicada em vida do autor (sobretudo se foi revista manifestamente por ele) a que ficará como fiável. Mas... é como se Redol tivesse querido legar-nos dois textos com o mesmo projecto, sublinhando implicitamente que dedicou anos de

\footnotetext{
21 "Ficha 14», Seara Nova, 11 de Abril de 1942.

22 Eu conheci directamente essa exigência, por ter sido sua aluna de Literatura no Secundário (antigo $7^{\circ}$ ano do Liceu), e posso testemunhar que ela era directamente proporcional ao saber que nos incutia e, em particular, ao modo como suscitava a nossa reflexão pessoal. Ele não exigia de nós, antes fazia com que nós exigíssemos de nós próprios, e por isso me parece compreender tão bem, nesta situação, o sentimento de Redol, que não tive o privilégio de conhecer (ele morreu no ano em que o meu filho nasceu).
} 
vida à tentativa dramática que pretendeu (como diz no prefácio admirável que é "O romance deste romance») «estabelecer o equilíbrio entre a paixão e a lucidez, entre o coração quente, em fogo, e o raciocínio quase matemático, empreendedor e terso». E a alusão a Mário Dionísio, e à sua crítica aguda e contundente, retoma praticamente as palavras deste, ao dizer que procurou alcançar "a chave da vida inteira de cada personagem, o tom justo, mesmo quando exaltado, a simplicidade, a palavra». E quem ler o exemplar que, desta $5^{\text {a }}$ edição refundida de Avieiros, Redol ofereceu ao seu crítico e amigo, verá na dedicatória manuscrita em folha de rosto estas palavras comoventes:

Devo à tua sinceridace e à tua camaradagem, Mário Dionísio, muito daquele pouco que hoje sou. / Quero dizer-te hoje, de olhos nos olhos, com a lucidez de quem se rasga todos os dias para se situar neste mundo. / Obrigado!

E não sei que mais admirar: se a coragem crítica de um (ao admoestar tão violentamente um amigo e colega), se a coragem de resistente do outro (ao perseverar e, trinta anos depois, ainda voltar atrás e emendar-se). O que sei é que criaturas deste estofo moral e tão elevado conceito do trabalho literário (de qualquer trabalho) merecem um profundo respeito, e o nosso dever de os conhecer melhor.

\section{Intensidade do texto de Redol}

Um dos grandes prazeres do leitor (mesclado de não pouca curiosidade) consiste então em inserir-se neste devir do texto, acompanhando a reflexão crítica e prática de Redol quando modifica romances dos anos quarenta para seguir vias de composição mais elaboradas. Além de se fruir também do acompanhamento da criação literária do próprio Mário Dionísio, concomitantemente, já que a correcção do trabalho de outrem tem efeito de ricochete no nosso próprio, se a componente deontológica nos move. Para mais, aliada à forte amizade e aos interesses comuns que a ambos irmanavam.

Mas o prazer maior é, em relação a Avieiros, o de empreender o cotejo das duas versões, verificando supressões e acréscimos, admirando substituições e 
alterações, e concluindo que, de facto, escrever um romance é trabalho difícil, racional, muito atento e demorado. Mas que amplamente compensa, se há talento e apego aos objectivos. Porém, comparar os dois textos é trabalho imenso. Só uma tese poderá dar dele conta com razoabilidade, e mesmo assim apenas delineando caminhos e avançando hipóteses de conclusão, o que será bastante, pois com frutos certos contará.

O que aqui se pode adiantar é que, na $2^{\mathrm{a}}$ versão de Avieiros, há, de facto, muitas alterações estilísticas, assinaláveis transformações de efabulação, e bastantes mudanças na composição geral do romance. Além de cortes de economia de meios, mutações para o enriquecimento do mundo romanesco, acréscimos que tornam mais densa a vivência de seres e situações. E personagens de recorte mais acabado, acerto maior na expressão do colectivo, e uma insistência na expressão poética que corrige o sentimentalismo do fraseado tópico e acentua a irradiação expressiva.

«Pelos seus caminhos próprios, Redol chegou ao sempre invejável domínio dos materiais ${ }^{23}$, escreverá Mário Dionísio dez anos depois da sua crítica devastadora, a propósito de Os Homens e as Sombras, romance em relação ao qual acrescenta: «toda a hesitação, todo o primarismo de construção, todo o sentimentalismo exaltado que tapa lacunas, toda a personagem títere, toda a pressa de provar, toda a linguagem aliteratada que arripia, todo o amadorismo, enfim, desaparecem das páginas do autor de Avieiros». Ao dizer isto, o escritor de Não há morte nem princípio (1969) está, sem o saber, a falar da redacção definitiva do romance que tão acerbamente criticou, e cuja publicação definitiva se verificará pouco antes do seu próprio, um ano antes da morte do amigo que espicaçou. E deixem-me aqui pensar que o bizavô campino acharia que o neto investiu, e não de imediato, com a nobreza do perfeito touro bravo! Redol viveu a mágoa da incompletude, da insatisfação que a amizade intensifica. E risonhamente pensarei também que a lembrança de D. Ana da Guia, a avó avieira, terá vindo ao encontro dos dois amigos (que na exigência de uma nova estética se encontravam, e se desencontravam no iníco da sua concretização) para os agraciar benevolamente no mútuo ardor dessa luta pela expressão ${ }^{24}$.

23 "Os Homens e as Sombras", Vértice, vol. XI, n 97, Setembro 1951.

24 Convoco aqui, risonha eu também, e nostálgica, o título de um livro de Fidelino de Figueiredo, A Luta pela Expressão, que nada terá a ver com isto em superfície, mas terá tudo, na profundidade dos escritos. 
Noutro sítio falo em pormenor do tipo de alterações verificadas na remodelação de Avieiros $^{25}$, bem como da poética da sua transformação. Interessa-me é salientar desde já que, em meu entender, o texto transformado não é um texto revisto, ou corrigido, antes a própria concepção da entidade-texto (em vez de um objecto-texto) inspirando (não organicamente, antes espiritualmente) o seu outro-texto, que não é um «texto outro» (no sentido da teorização de Julia Kristeva, isto é: um negativo, ou um duplo) mas «O» texto que a si mesmo se reconhece, uma vez alterado (outrado) como sendo ele-próprio. E o escritor (o crítico, o leitor) segue atrás dele. De certo modo, estamos no domínio do que Antoine Compagnon designa como a "a segunda mão" ${ }^{26}$ e, nesta, da "fachada" ${ }^{27}$, em que certos textos, imagens, ou textos-imagens desenvolvem, na sua relação com o texto em si, uma relação dupla ou múltipla (desdobrada), de imediatez ou profundeza, de cumplicidade desafiante e autonomia relativa também. Por isso, um passo há, na "Breve história», que dá conta do enorme salto que Alves Redol efectuou, nesses quase trinta anos, ao passar da «experiência, [...] que tornei carne viva dos meus livros»" ${ }^{28}$, para o domínio da palavra: "A palavra-pele que cobre cada passo de um mundo emaranhado de sugestões inquietas e inquietantes, a palavra-pele que só ela pode viver ali, exactamente ali, como a das minhas mãos ou a das tuas, que enfeixa músculos e tecidos, sangue, vida ${ }^{29}$.

Essa descoberta da palavra, que já não é só elemento de transferência para a figuração do mundo pretendido mas parte desse mundo, e até, em larga medida, seu elemento constituinte fundamental (componente da representação do mundo e, logo, parte da convenção literária que cada texto, de per si, vem quebrar), quereria ele comunicá-la aos companheiros de leitura da $1^{\mathrm{a}}$ edição, que evoca, dando o nome de dois queridos desaparecidos: Soeiro Pereira Gomes e Carlos

25 Procederei ao breve cotejo destas edições num dos próximos volumes da revista Nova Sintese, que publicará as comunicações apresentadas ao Congresso do Centenário de Alves Redol realizado pelo Centro de Estudos Comparatistas na Faculdade de Letras de Lisboa e no Museu do Neo-Realismo em Vila Franca de Xira. Ver a nota 1. deste trabalho.

26 Antoine Compagnon, La seconde main, ou le travail de la citation, Seuil, Paris, 1979.

27 Id., ib., pp. 333-4.

28 E acrescenta: "Embora o engenho de escritor não me bastasse ainda para interpretar e recriar o que a realidade lhe oferecia, elevando-a ao nível da significação», em reflexão de tipo metalinguístico de quem se tornou consciente dos problemas que a escrita coloca.

29 Avieiros, $5^{\text {a }}$ ed., 1968, pp. 18-19. Ver pág. 274 deste trabalho. 
Pato. Num universo de amigos e companheiros comuns, que constitui a ambiência neo-realista.

Por isso mesmo, quando lemos Redol hoje, na decorrência das comemorações do seu Centenário, estas palavras de Mário Dionísio, de 197930, ganham redobrada força: «Toda a obra de Redol está de novo em causa. Não para exaltá-la porque sim, nem para recusá-la porque não. O que importa é relê-la, estudá-la, efectivamente conhecê-la com os nossos olhos, de hoje. Que outra via não há para admirá-la de facto». E, estudando-a, captamos nela uma intencionalidade, no sentido husserliano, que um tanto a desvia da decidida rota inicial porque, como ele acompanha o seu tempo, o ponto de destino se desloca também. Acompanha? O tempo faz os homens ou são estes que o fazem? O tempo, enquanto duração do lugar, é independente do esforço humano, que é perecível, como a sua intencionalidade. Mas o lugar, mesmo mutável, parece resistir. Mesmo sendo o vazio do que foi. Tal como resiste a Vieira (a localização matriz de Vieira de Leiria), mesmo com os seus homens ausentes, em Avieiros - na memória do que foram, na intensão do que agora buscam. E no intensamente vivido que se comunica a Redol nos contos de Jerónimo Tarrinca, e faz do conflito da vida a intensidade do viver. Ao reescrever Avieiros, o autor de Marés intensifica um labor que acaba por postergar o documentalismo, ou antes: respeita-o, pois quer dar a imagem da realidade - mas prolonga-o em imagística própria, no trabalho do escritor em recriação.

Confrontar as duas versões de Avieiros é tarefa lenta, que só um trabalho de escopo académico de fundo suportará. Mas muito há-de revelar sobre o introdutor do Neo-Realismo, e muitíssimo sobre a arte do romance, com particular ganho para os estudos da representação literária, das convenções estilísticas da ficção, e da produtividade do texto de carácter poético.

* Por vontade da autora, o presente texto não segue as normas do novo Acordo Ortográfico.

30 "A quarenta anos de Gaibéus", Diário de Lisboa, 31.12.79. 